\title{
Pengambilan keputusan suami istri dalam menentukan pendidikan anak: Studi pada Muslimat Hidayatullah Surabaya
}

\section{Taking decision husband wife in determining children's education: Study in Hidayatullah Muslimat Surabaya}

\author{
Siti Faridatus Sa'adah \\ Departemen Sosiologi, Fakultas Ilmu Sosial dan Ilmu Politik, Universitas Airlangga \\ Surabaya, 60286, Jawa Timur, Indonesia \\ E-mail: siti.faridatus.saadah-2014@fisip.unair.ac.id
}

\begin{abstract}
Abstrak
Keluarga adalah institusi ketahanan yang terkuat dan setiap manusia begitu terikat pada keluarga, karena setiap orang dilahirkan dalam keluarga. Setiap keluarga berfungsi sebagai pengantar untuk masyarakat yang lebih besar, sebagai hubungan pribadi dengan struktur sosial yang lebih besar. Kekuatan sosial keluarga adalah aspek yang tidak dapat ditemukan di institusi lain. Penelitian ini bertujuan untuk menguji pengambilan keputusan dalam menentukan pendidikan anak. Para ibu Muslimat Hidayatullah di Kota Surabaya sekaligus istri sebagai pendidik utama bagi anak-anak untuk mendapatkan pendidikan dan suami terbaik dengan peran mereka, yang lebih kuat dalam membuat keputusan suami dan istri untuk menentukan pendidikan anak-anak mereka. Penelitian ini menggunakan metode penelitian kualitatif dan teori pengambilan keputusan oleh George R. Terry dan teori hubungan kekuasaan oleh Faucault. Pengambilan informan dilakukan dengan teknik purposive. Data diperoleh tujuh informan subjek dan tiga informan non subjek. Ada beberapa hasil yang diperoleh dari penelitian ini. Pertama, suami lebih dominan ketika dia memiliki akses ke pengetahuan dalam pendidikan, kemampuan ekonomi untuk memenuhi semua kebutuhan suami, dan pemahaman agama. Kedua, istri lebih dominan ketika dia memiliki akses ke pengetahuan tinggi dan keterampilan ekonomi yang sama dengan suaminya. Ketiga, diskusi dan musyawarah adalah jalan yang dipilih oleh suami dan istri untuk mempertimbangkan sekolah. Terakhir, sekolah Hidayatullah dipilih untuk pendidikan anak-anak mereka karena mereka menganggapnya sebagai tempat terbaik untuk menjaga agama.
\end{abstract}

Kata kunci: pengambilan keputusan; hubungan kekuasaan; pendidikan; pengetahuan; anak-anak

\begin{abstract}
The family is the strongest institution of endurance and every human being is so attached to the family, because everyone is born into a family. Each family functions as an introduction to the larger society, as a personal link with the larger social structure. The social strength of the family is an aspect that cannot be found in other institutions. This study aimed to examine the decision making in determining the education of children. The mothers of Muslimat Hidayatullah in Surabaya City The wife as the main educator for children to get the best education and husband with their role, who is more powerful in making husband and wife decisions to determine their education of children. This study used qualitative research methods, used the decision making theory by George R. Terry's and power relations theory by Faucault. The informants taking was done through purposive technique The data were obtained seven subject informants and three non-subject informants. There are some results obtained from this research. Firstly, the husband is more dominant when he has access to knowledge in education, the economic ability to meet all the needs of the husband, and the understanding of religion. Secondly, wife is more dominant when she has access to high knowledge and the same economic skills as her husband. Thirdly, discussions and deliberations are the paths chosen by husband and wife to consider school. Lastly, Hidayatullah school is chosen for their children education because they consider it as the best place to guard religion.
\end{abstract}

Keywords: decision making; power relations; education; knowledge; children

\section{Pendahuluan}

Keluarga merupakan lembaga yang paling kuat daya tahannya dan setiap manusia begitu lekat dengan keluarga, karena setiap orang dilahirkan dalam keluarga. Setiap keluarga berfungsi sebagai pengantar pada masyarakat besar, sebagai penghubung pribadi dengan struktur sosial yang lebih besar (Wilson \& Pahl 1988; Mitchell 2017; Gurko 2017). Kekuatan sosial yang dimiliki keluarga merupakan aspek yang tidak dapat ditemukan pada lembaga lain, yaitu kemampuan mengendalikan individu secara 
terus-menerus. Berfungsinya keluarga dengan baik merupakan prasyarat mutlak bagi kelangsungan suatu masyarakat, karena di dalam keluarga suatu generasi yang baru memperoleh nilai-nilai dan norma yang sesuai dengan harapan masyarakat. (Ihromi 1999).

Pendidikan merupakan wadah pengembangan ilmu pengetahuan, baik tidaknya seseorang maupun masyarakat dikembalikan kepada benar tidaknya ilmu yang dipelajari. Kekeliruan dalam ilmu menyebabkan pemikirannya tidak beradab (Hasib 2016). Hidayatullah merupakan organisasi massa islam yang berbasis kader. Hidayatullah menyatakan diri sebagai Gerakan Perjuangan Islam dengan dakwah dan tarbiyah sebagai program utamanya. Hidayatullah adalah salah satu contoh ormas Islam yang menyediakan lembaga pendidikan yang berbeda dengan lainnya, mata ajaran dari Kemendikbud dan ditekankan juga pada agama.

Selain itu, Hidayatullah mempunyai pesantren yang berfungsi sebagai tempat untuk mendalami ilmu. Pesantren ini dihuni santri yang tinggal di asrama, guru, pengasuh, pengelola dan jamaah Hidayatullah. Pola pengajaran di Pesantren Hidayatullah adalah sistem pesantren modern, yaitu penggabungan mata ajaran umum Kemendikbud dan mata ajaran khusus atau keislaman (diniyah). Mata ajaran umum sama seperti mata ajaran pada sekolah-sekolah umum lainnya, contohnya matematika, fisika, kimia dan lain lain. Mata ajaran khusus yaitu mata ajaran yang berkaitan dengan keislaman, contohnya aqidah, fiqih, bahasa Arab, dan hafalan/tahfidz Al Qur'an, serta masih banyak lagi mata ajaran yang lain, sesuai dengan jenjang pendidikan dan letak kampus.

Secara sosiologi, pengambilan keputusan sebagai hal yang pasti dialami oleh semua keluarga untuk menghasilkan keputusan yang baik (Newman \& Grauerholz 2002). Proses pengambilan keputusan dilakukan dengan tujuan terbentuknya anak-anak yang berkarakter dan berkualitas sesuai dengan norma, nilai, maupun aturan agama yang diyakini dalam suatu keluarga. Dengan tujuan tersebut, orang tua tidak akan mengambil keputusan yang sembarangan terkait pendidikan anak. Penelitian dilakukan kepada pengemban dakwah Islam, dimana pengemban dakwah akan taat pada aturan Islam.

Apapun yang dilakukan berdasarkan bagaimana islam mengatur, seperti menikah untuk bersama dalam dakwah dengan salah satunya mengikuti pernikahan massal sehingga berasal dari lembaga yang sama. Suami yang bekerja dan istri hanya dirumah mengurus rumah dan mendidik anak sesuai islam. Dengan demikian apakah istri tetap memiliki hak dan peran dalam menentukan pendidikan anak atau semua keputusan berasal dari suami. selain itu jika istri memiliki pendapatan sendiri dan aktif dakwah di bidang pendidikan, apakah keputusan ada pada suami atau istri. Maka peneliti mengangkat fenomena sosial mengenai pengambilan keputusan dalam menentukan pendidikan anak yang dilakukan oleh Muslimat Hidayatullah (Mushida).

Menurut George R. Terry (1960) definisi pengambilan keputusan adalah pemilihan alternatif perilaku dari dua alternatif atau lebih. Sementara menurut Siagian (1974), pengambilan keputusan adalah suatu pendekatan terhadap hakikat suatu masalah, pengumpulan fakta-fakta dan data, penentuan yang matang dari alternatif yang dihadapi, dan pengambilan tindakan yang menurut perhitungan merupakan tindakan yang paling tepat. Dari kedua pengertian di atas maka dapat ditarik kesimpulan bahwa keputusan itu diambil dengan sengaja, tidak secara kebetulan, dan tidak boleh sembarangan. Masalahnya terlebih dahulu harus diketahui dan dirumuskan dengan jelas, sedangkan pemecahannya harus didasarkan pemilihan alternatif terbaik dari alternatif yang ada.

Pengambilan keputusan sebagai suatu kelanjutan dari cara pemecahan masalah memiliki fungsi, antara lain pangkal permulaan dari semua aktivitas manusia yang sadar dan terarah, baik secara individual maupun secara kelompok. Sesuatu yang bersifat futuristik, artinya bersangkut paut dengan hari depan, masa yang akan datang, di mana efeknya atau pengaruhnya berlangsung cukup lama.

Menurut John D. Millett (2009) faktor-faktor yang berpengaruh dalam pengambilan keputusan adalah, antara lain pria dan wanita, pria pada umumnya bersifat lebih tegas atau berani dan cepat dalam mengambil keputusan dan wanita umumnya relatif lebih lambat dan sering ragu-ragu, peran pengambil keputusan, peran bagi orang yang mengambil keputusan itu perlu diperhatikan, termasuk 
dalam hal kemampuan untuk mengumpulkan informasi, kemampuan menganalisis dan menginterpretasikan suatu masalah. Selanjutnya, keterbatasan kemampuan, perlu disadari adanya kemampuan yang terbatas dalam pengambilan keputusan akan berdampak pada hasil keputusan itu sendiri. Keputusan merupakan hasil pemecahan masalah secara tegas, hal tersebut berkaitan dengan permasalahan yang sedang dihadapi. Dapat juga dikatakan bahwa keputusan itu sesungguhnya merupakan hasil proses pemikiran yang berupa pemilihan satu diantara beberapa alternatif yang dapat digunakan untuk memecahkan masalah yang dihadapinya (Anggreany 2015).

Sementara itu, kekuasaan adalah sesuatu yang dilegitimasikan secara metafisis kepada negara yang memungkinkan negara dapat mewajibkan semua orang untuk mematuhinya (Abbott \& Wallace 2016). Namun menurut Faucault (2002), kekuasaan adalah satu dimensi dari relasi. Di mana ada relasi, di sana ada kekuasaan. Teori Relasi Kekuasaan Michel Faucault, dalam genealogi kekuasaan, Faucault membahas bagaimana orang mengatur diri sendiri dan orang lain melalui produksi pengetahuan. Di antaranya, ia melihat pengetahuan menghasilkan kekuasaan dengan mengangkat orang menjadi subjek dan kemudian memerintah subjek dengan pengetahuan. Ia mengkritik penyusunan pengetahuan secara bertingkat (hierarki pengetahuan). Karena bentuk tingkatan tertinggi pengetahuan (ilmu pengetahuan) mempunyai kekuasaan terbesar, maka ilmu pengetahuan dikhususkan untuk dikritik paling keras. Foucault yakin bahwa pengetahuan dan kekuasaan selalu bersaing antara keduanya selalu terjadi resistensi (Ritzer 2014).

Teori Relasi Kekuasaan Michael Faucault menjelaskan bagaimana kekuasaan bersifat persuasif di mana kekuasaan hadir di dalam semua relasi sosial, tidak hanya dalam kehidupan bernegara, namun kekuasaan juga terdapat dalam relasi antara mahasiswa senior dan junior. Faucault mengemukakan teorinya mengenai wacana sebagai pengetahuan yang terstruktur, aturan, praktik yang menghasilkan pernyataan bermakna pada satu rentang historis tertentu. Oleh karena itu, wacana erat hubungannya dengan kekuasaan. Ia berpendapat bahwa konsep kekuasaan telah berubah dibandingkan dengan abad ke-19. Ciri kekuasaan pada saat itu: pertama, cenderung brutal. Kedua, dioperasikan secara terusmenerus. Ketiga, menekankan ketaatan pada tata cara dan penuh dengan simbolisme. Keempat, berada di ruang publik. Kekuasaan, menurut Foucault, bukan milik siapa pun, kekuasaan ada di mana-mana, kekuasaan merupakan strategi.

Kekuasaan adalah praktik yang terjadi dalam suatu ruang lingkup tertentu -ada banyak posisi yang secara strategis berkaitan satu dengan yang lain dan senantiasa mengalami pergeseran. Kekuasaan menentukan susunan, aturan, dan hubungan dari dalam. Kekuasaan bertautan dengan pengetahuan yang berasal dari relasi-relasi kekuasaan yang menandai subjek. Karena Foucault menautkan kekuasaan dengan pengetahuan sehingga kekuasaan memproduksi pengetahuan dan pengetahuan menyediakan kekuasaan, ia mengatakan bahwa kekuasaan tidak selalu bekerja melalui penindasan dan represi, melainkan juga normalisasi dan regulasi (Sutrisno 2005).

\section{Metode Penelitian}

Fokus dan tujuan dari penelitian ini adalah untuk memahami bagaimana pengambilan keputusan pendidikan anak pada Muslimat Hidayatullah (Mushida), terkait dengan beberapa model pendidikan yang bisa dipilih oleh keluarga dengan memilih pendidikan yang terbaik untuk anaknya. Semua pertanyaan dari studi ini dapat ditemukan jawabannya melalui paradigma definisi sosial yang berupaya untuk memahami dan menjelaskan perilaku kehidupan manusia secara individu maupun manusia sebagai makhluk sosial yang berinteraksi dengan lingkungannya.

Paradigma definisi sosial dipilih karena paradigma ini cocok digunakan untuk memahami kehidupan keluarga pengemban dakwah islam (Mushida) lebih mendalam. Studi ini menggunakan data-data kualitatif, serta subjek dalam penelitian ini adalah istri yang menjadi ibu dan pendidik utama bagi anak-anaknya. 


\section{Hasil dan Pembahasan}

\section{Proses pengambilan keputusan dalam keluarga}

Proses pengambilan keputusan dalam menentukan pendidikan anak memerlukan pemikiran yang lebih dan rasional (Dornbusch et al. 1990; Anderson, Minke 2007). Proses ini dilakukan agar anak mendapatkan pendidikan yang terbaik dan berkualitas. Selain itu dengan pemahaman keluarga pengemban dakwah bahwa anak amanah yang nantinya akan dipertanggung jawabkan salah satunya bagaimana orangtua dalam mendidik anak, karena pendidikan adalah hak anak dan memberikan pendidikan terbaik adalah kewajiban orangtua. Setiap anak mempunyai hak dan kesempatan untuk mengembangkan segala potensi yang dimilikinya (Daniel et al. 2009). Sebab pendidikan anak saat ini akan mempengaruhi masa depan anak.

Oleh karena itu, orangtua disarankan untuk memilihkan sekolah sesuai minat dan bakat anaknya. Ada orang tua yang mengambil dengan berani menyekolahkan anak di sekolah sekuler (agama dan kehidupan terpisah) dengan komitmen akan memfilter semua pengetahuan yang merusak pemikiran anak dan menyiapkan menjadi anak ideologis pengemban dakwah sejak dini. Atau alasannya karena mahalnya biaya untuk memasukkan anak di sekolah terpadu. Hal tersebut sesuai pandangan George R. Terry (1960), definisi pengambilan keputusan adalah pemilihan alternatif perilaku dari dua alternatif atau lebih. Sementara menurut Siagian (1974), pengambilan keputusan adalah suatu pendekatan terhadap hakikat suatu masalah, pengumpulan fakta-fakta dan data, penentuan yang matang dari alternatif yang dihadapi, dan pengambilan tindakan yang menurut perhitungan merupakan tindakan yang paling tepat. Bagaimana tindakan yang tepat yang diambil orangtua dalam menentukan pendidikan untuk anaknya.

Setiap orang tua tentunya menginginkan pendidikan yang terbaik untuk anaknya, ketika saat masih berada di lingkungan keluarga anak telah dididik dengan baik dan Al-Quran dan As-Sunah. Namun ketika memasuki pendidikan formal tentu orang tua akan selektif terhadap sekolah yang akan dimasuki anaknya (Denessen \& Driessena 2005), sehingga dalam menentukan lembaga pendidikan yang tepat bagi anak, keluarga anak telah dididik dengan baik dan Al-Quran dan As-Sunah. Namun ketika memasuki pendidikan formal tentu orang tua akan selektif terhadap sekolah yang akan dimasuki anaknya. Sehingga dalam menentukan lembaga pendidikan yang tepat bagi anak, YM dan suami mengutamakan lingkungannya. Oleh sebab itu, sebelum menentukan sekolah untuk anaknya, YM selalu melihat lingkungan sekolah tersebut. YM dan keluarganya memutuskan tinggal di lingkungan Hidayatullah karena dari awal memang mencari suasana yang islami dan dekat dengan masjid untuk mendidik anaknya yang laki-laki dengan dibiasakan sholat di masjid karena laki-laki lebih utama sholat di masjid. Sehingga, ia ingin anaknya juga sekolah di Hidayatullah.

YM memilih di Hidayatullah karena pendidikan yang diajarkan adalah pendidikan agama. YM dan suami melakukan percobaan terhadap anaknya yang pertama dengan mencoba memasukkan di universitas umum dengan pertimbangan anaknya yang pertama sudah bisa mempertanggung jawabkan yang dilakukan maka YM berani untuk memasukkan anaknya di universitas umum bukan islam. Setelah percobaan itu YM tidak ingin lagi memasukkan anaknya di sekolah maupun universitas umum dan anaknya yang pertama juga menyarankan ke adik-adiknya untuk tidak sekolah di umum dan cukup kakaknya saja yang meraskan karena ketika iman tidak kuat seorang tidak akan kuat dengan pergaulan yang ada, karena pergaulan sebelumnya yang sangat dijaga dan terkondisikan tentu akan membuat seorang kaget dengan pergaulan di luar.

Dalam hal ini tentu membutuhkan hubungan yang baik antara orang tua dan anak, orang tua harus paham keinginan anak dan jika keinginan tersebut membahayakan anak, orang tua harus segera mengarahkan anak. hubungan antara orang tua dan anak harus terjalin dengan baik untuk keberhasilan anak. yaitu dengan memberikan kasih sayang dan perhatian terhadap anak. Tanggung jawab keluarga bagi pendidikan anak adalah sebagai berikut; memelihara dan membesarkannya, tanggung jawab ini merupakan dorongan alami untuk dilaksanakan karena si anak memerlukan makan, minum, dan perawatan agar dia dapat hidup secara berkelanjutan; melindungi dan menjamin kesehatannya, baik 
secara jasmani maupun rohaniah dari berbagai gangguan penyakit atau bahaya lingkungan yang dapat membahayakan dirinya; mendidiknya dengan berbagai ilmu pengetahuan dan ketrampilan yang berguna bagi kehidupannya kelak sehingga bila ia telah dewasa mampu berdiri sendiri dan membantu orang lain; membahagiakan anak untuk dunia dan akhirat dengan memberinya pendidikan agama sesuai dengan ketentuan Allah SWT, sebagai tujuan akhir kehidupan muslim (Hasbullah 2009).

Sedangkan SF dalam menentukan pendidikan anak karena percaya dengan lembaga yang selama ini suaminya bekerja. Hal itu membuat SF memutuskan bergabung dengan lembaga Hidayatullah dan menyekolahkan semua anaknya di Hidayatullah. SF melihat sekolahnya yang bagus ia merasa cocok dari segi agama yang diutamakan, pendidikan juga sangat diperhatikan dan anak dididik dengan sangat baik oleh pengajar yang sangat sabar mengajari siswa, selain itu juga akidah anak kuat karena terkondisikan di sekolah tersebut. Namun yang diberatkan oleh SF adalah dari segi dana yang mahal untuk membayar sekolah karena SF menyadari sekolah yang dipilih adalah swasta.

Menurut LST pendidikan anak sangat penting, pendidikan tidak hanya formal karena pendidikan itu mulai dari kandungan sampai ke liang lahat pendidikan tidak boleh berhenti. Sangat pentingnya orangtua memberikan pendidikan kepada anak karena pendidiakan itulah bekal anak, jika orang tua tidak mampu memberikan pendidikan maka orangtua membutuhkan seperti pendidikan formal dan pendidikan agama, dan ketika tidak mampu tetap harus diusahakan karena itu merupakan amanah yang nantinya akan dipertanggung jawabkan.

Pendidikan dalam keluarga hakikatnya merupakan proses pendidikan sepanjang hayat. Pembinaan dan pengembangan kepribadian penguasaan dasar-dasar ilmu islam dan lainnya dilakukan melalui pengalaman sehari-hari dan sumber belajar di keluarga. Itulah mengapa proses pendidikan dalam keluarga disebut sebagai pendidikan yang pertama dan utama, karena ia menjadi peletak pondasi kepribadian anak (Bosetti 2004). Keluarga adalah wadah pembinaan keislaman untuk setiap anggotanya yang sekaligus akan membentenginya dari pengaruh negatif yang berasal dari luar (Badawi 2006).

Dalam dakwah pun, sebelum menyeru masyarakat luas, seorang muslim diperintahkan untuk berdakwah terlebih dahulu kepada anggota keluarga dan kerabat dekatnya. Pendidikan dalam keluarga semestinya telah dimulai sejak usia anak dalam kandungan hingga menginjak usia baligh dan memasuki jenjang pernikahan, dan bahkan akan terus berlangsung hingga usia tua. Pertama, pendidikan pada saat anak masih dalam kandungan, menjelang turunnya malaikat untuk meniupkan roh, disertai catatan tentang empat perkara, yakni rezeki, umur, amal, dan nasib. Ibu mendidik anak bayi tersebut dengan memperbanyak do'a kepada Allah SWT agar anaknya menjadi pribadi saleh, berbakti kepada orangtua dan bermanfaat bagi umat dan agamanya. Kedua, pendidikan anak pascca lahir hingga baligh (postnatal) ketika seorang anak lahir, Islam mengajarkan untuk mendidik dan mengembangkan aspek tauhid, antara lain dengan membacakan adzan di telinga kanan dan iqomat di telinga kiri. Ilmu pengetahuan modern membuktikan bahwa panca indra manusia yang pertama kali berfungsi adalah pendengaran. Menurut hasil penelitian diketahui bahwa satu menit setelah kelahiran, bayi mulai dapat menangkap bunyi-bunyi yang membuatnya segera memalingkan wajah ke arah datangnya suara. Kemudian pendidikan berupa pemberian nama yang baik, pemberian air susu ibu, dan penanaman keteladanan kepribadian islam serta pemberian tuntunan untuk berumah tangga (Yusanto 2004).

LST memilihkan sekolah yang terbaik untuk anaknya dan yang sesuai dengan kemampuan anak. Selain itu, ingin anak mengenal lembaga di mana orangtuanya bergabung, dengan bantuan pengajar di Hidayatullah yang sama visinya seperti LST. Meskipun di lembaga sendiri tidak ada jaminan anak akan tetap baik karena yang masuk di sekolah Hidayatullah anak-anak umum juga. Bagi LST menyekolahkan anak tidak harus di Hidayatullah tetapi dimana saja anak bisa mendapatkan ilmu, karena bagi LST suatu saat nanyi di Hidayatullah akan membutuhkan tenaga pengajar yang paham AlQuran yang mampu hadistnya dan ilmu lainya dan ketika tidak demikian lembaga pendidikan Hidayatullah tidak akan berkembang. Sementara bagi keluarga SFA pendidikan anak adalah suatu yang harus diutamakan dalam keluarga, dimana SFA saat ini merasa menyesal karena ia hanya lulusan 
SMA, ia tidak melanjutkan pendidikannya karena untuk memberikan kesempatan adik-adiknya merasakan pendidikan, keterbatasana ekonomi keluarga membuat SFA menghentikan pendidikannya. Sehingga saat ini, SFA merasa susah untuk mencari pekerjaan dengan modal ijazah SMA. SFA dan suaminya memilih pendidikan yang berbasis tauhid untuk anaknya. Sekolah Hidayatullah adalah berbasis tauhid dan pendidikan umum dari Diknas juga. Selain itu SFA adalah guru tahfidz ibu-ibu Mushida dan wali murid yang mengikuti tahfidz, jadi SFA juga menginginkan anaknya tahfidz dan di Hidayatullah juga menggunakan program tahfidz dengan berbagai target hafalan untuk siswa dengan target hafalan yang berbeda setiap tingkatan sekolahnya. Begitu pula dengan AN yang bermusyawarah dengan suaminya dalam menentukan pendidikan anak dan memilih pendidikan berbasis agama.

\section{Relasi kuasa suami istri dalam menentukan pendidikan anak}

Berbicara kekuasaan berarti membicarakan dua pihak, ada pihak yang menguasai ada pihak yang dikuasai. Begitu juga di dalam sebuah keluarga yang hubungannya berdasarkan kasih sayang dengan berbagai tugas masing-masing dari istri maupun suami. Suami yang bertugas untuk mencari rezeki untuk memenuhi kebutuhan keluarganya dan seorang istri yang memliki multifungsi dan peran dalam keluarga, seperti sebagai isteri, partner bagi suaminya, pengatur rumah tangga, ibu bagi anak-anak, dan pendidik utama bagi anak-anaknya, dan bagi pengemban dakwah dengan kewajibannya untuk berdakwah. Menurut Michel Foucault, dalam genealogi kekuasaan, Foucault membahas bagaimana orang mengatur diri sendiri dan orang lain melalui produksi pengetahuan. Di antaranya ia melihat pengetahuan menghasilkan kekuasaan dengan mengangkat orang menjadi subjek dan kemudian memerintah subjek dengan pengetahuan. Ia mengkritik penyusunan pengetahuan secara bertingkat atau hierarki pengetahuan (Ritzer 2014).

Pengetahuan yang dimiliki ayah maupun ibu digunakan untuk menjalankan peran atau kewajiban masing-masing dalam keluarga. Dalam islam kewajiban nafkah bagi ayah adalah pangan, papan, dan sandang (Ahmad 1974; Carolan et al. 2000; Predelli 2004). Beban berat yang ditanggung ayah tersebut, tidak jarang seorang ibu pun mengambil posisi membantu ekonomi keluarga. Sehingga tugas mendidik anak adalah tugas ibu dan ayah menyediakan keperluan termasuk uang. Ibu terkadang tidak berdaya dihadapkan suatu kondisi harus menangani sendiri pendidikan anak tanpa ada bantuan dari ayah. Ibu adalah orang yang paling berambisi menjadikan anaknya memiliki kepribadian yang islam yang tangguh sehingga berupaya mencari tahu cara mendidik anak dan berbagai training diikuti hingga mencari berbagai referensi tentang parenting. Inilah sebabnya suami menyerahkan kepercayaan penuh pada istrinya untuk mendidik anak (Tanjung 2017).

Menurut Faucault seorang bisa menguasi pihak lain berdasarkan pengetahuan atau pendidikan, semakin tinggi pendidikan itulah yang akan berkuasa. Pendidikan YM lebih rendah daripada suaminya, dimana YM lulusan D3 Busana dan suaminya adalah S1. Menurut Faucault berdasarkan pendidikan suami YM yang lebih berkuasa dalam menentukan pendidikan anak. Namun, ternyata tidak selalu benar pengetahuan atau pendidikan yang lebih tinggi yang lebih berkuasa (Freire 1985; Ball 2012). Keluarga YM dalam menetukan pendidikan anak, tingginya pendidikan suami tidak menjadikan suami YM lebih berkuasa untuk mengambil keputusan, karena pemahaman YM, bahwa lelaki atau suami adalah pemimpin bagi wanita. Setiap apa yang akan dilakukan YM harus mendapatkan izin dari suaminya.

YM dan suami yang sama-sama memiliki kekuatan ekonomi dalam keluarga, suami dengan pekerjaanya di Hidayatullah dan istrinya yang memiliki bisnis jahit yang telah dirintis sebelum menikah. Dalam menentukan pendidikan anak YM dan suami mempunyai kekuatan untuk menentukan pendidikan anak. Musyawarah dan diskusi adalah jalan yang dipilih oleh YM dan suami dalam menentukan pendidikan anaknya, yaitu dengan mempertimbangkan kurikulum, lembaga, dan lingkungannya. Sebelum itu, keluarga YM melakukan survey ke beberapa sekolah untuk menentukan sekolah mana yang diinginkan. Untuk keamanan anak, YM dan suami memilih menyekolahkan anaknya di Hidayatullah, selain karena sudah mengenal lingkungannya dengan baik, juga YM dan suami berada di lembaga tersebut. Dari segi ekonomi, YM yang memiliki bisnis busana yang sudah besar juga tidak mempengaruhi untuk YM memiliki kuasa untuk mengambil keputusan. Sedangkan 
dalam menentukan pendidikan anak keluarga YM selalu berdiskusi dan bekerjasama dalam menentukan pendidikan anaknya yaitu dengan mempertimbangkan kurikulum, lembaga, dan lingkungannya. Sebelum itu, keluarga YM survey ke beberapa sekolah untuk menentukan sekolah mana yang diinginkan, tetapi keputusan akhir pada suami.

Berbeda dengan SF yang hanya ibu rumah tangga biasa dan tidak ada pekerjaan selain mengurus tumah tangga dan anak. Suami SF mempunyai kekuatan dari segi ekonomi karena semua biaya pendidikan anak dan kebutuhan rumah tangga adalah dari suaminya. Selain itu, pendidikan suami SF lebih tinggi dari SF, dan menurut SF yang lebih mengetahui pendidikan yang terbaik untuk anak adalah suaminya. Sehingga, yang lebih berkuasa dalam pengambilan keputusan adalah suami. Ini sesuai teori relasi kuasa Foucault yang membahas bagaimana orang mengatur diri sendiri dan orang lain melalui produksi pengetahuan. Di antaranya, ia melihat pengetahuan menghasilkan kekuasaan dengan mengangkat orang menjadi subjek dan kemudian memerintah subjek dengan pengetahuan.

Pendidikan LST lebih rendah dari suaminya, di mana LST hanya lulusan S1 dan suaminya adalah lulusan S2. Menurut Faucault dilihat dari pendidikannya, suami LST yang lebih berkuasa dalam menentukan pendidikan anak. Dalam keluarga LST bukan pendidikan yang mempengaruhi, tetapi karena suami adalah pemimpin dalam keluarga dan semua biaya hidup termasuk pendidikan anak adalah dari suami LST, sehingga membuat suami LST lebih berkuasa dalam menentukan pendidikan anaknya. Pengambilan keputusan terjadi setelah musyawarah dan mengarahkan anak LST agar bersedia bersekolah di sekolahan yang telah dipilih orangtuanya. Sama dengan SF, LST juga menuturkan, ia dan suami selalu bermusyawarah dan mengarahkan anak-anaknya dan tidak memaksa anaknya untuk sekolah sesuai pilihan orangtua. SLT dan suami lebih memilih pondok untuk mendidik anak sehingga dari awal LST dan suami sudah memberikan arahan bahwa di pondok bukan hanya menghafal Al-Quran tetapi banyak ilmu yang di dapat ketika di pondok. Suami LST mempunyai kekuatan dari segi ekonomi sehingga yang mempunyai kuasa dalam penentuan pendidikan anak adalah suami LST.

Genealogi kekuasaan memperhatikan hubungan antara pengetahuan dan kekuasaan dalam ilmu kemanusiaan dan praktik-praktiknya yang berhubungan dengan regulasi tubuh, pengaturan perilaku dan pembentukan diri (Ritzer 2014). Pendidikan SFA lebih rendah dari suaminya, SFA lulusan SMA dan suaminya S1. Menurut Faucault, dilihat dari segi pendidikan suami SFA lebih berkuasa dalam pengambilan keputusan pendidikan anak. Hal ini, sesuai dengan kondisi dalam keluarga SFA di mana pengetahuan dari suami SFA ikut andil dalam pengambilan keputusan. Suami SFA yang menjadi pengajar di Pondok Pesantren Hidayatullah yang mengetahui bagaimana kondisi sekolah maupun pesantren disana. Selain itu, semua biaya hidup termasuk pendidikan anak yang semua ditanggung oleh suami juga mempengaruhi kekuatan suami dalam penambilan keputusan. Kuatnya kepemimpinan ayah dalam pendidikan anak sangat menentukan terealisasinya proses belajar anak. Ayah adalah polisi umum dan kepemimipinan umum dalam keluarga, maka ayah adalah orang yang paling pertama memahami konsep pendidikan. Peran ayah adalah sangat penting bagi keselamatan keluarga (Tanjung 2017).

AN dan suami pendidikan terakhirnya adalah S1, memiliki pekerjaan yang sama yaitu pengajar di Lembaga Pendidikan Hidayatullah, dan memiliki pendapatan masing-masing sebagai pengajar. Sehingga dalam pengambilan keputusan yang berkuasa adalah istri, karena dalam hal ini peran AN sebagai pendidik utama bagi anaknya dan memastikan anaknya mendapatkan pendidikan yang terbaik. Selain itu, AN juga memiliki akses atau dirinya yang memiliki jabatan dakwah di departemen pendidikan. Hal tersebut yang membuat AN memiliki kuasa dalam pengambilan keputusan pendidikan anaknya.

Di samping itu, ibu adalah yang mendidik anaknya dirumah, mengetahui pertumbuhan dan perkembangan anak. sedangkan, ayah seringkali keluar rumah apakah untuk menjalankan kewajiban mencari nafkah atau kewajiban dakwah, walaupun ayah mempunyai tanggung jawab yang sama terkait pendidikan anak (Putri \& Lestari 2016) agar anak tidak salah jalan atau terpengaruh dengan hal negatif, seorang ibu tidak boleh kalah dari siapapun dalam mempengaruhi anak seperti TV, keluarga 
besar, anak tetangga, game dan internet. Ibu harus membuat kegiatan harian bersama anak sehingga porsi kegiatan anak ada bersama ibu, jika ibu mempunyai kepentingan lain, misalkan mencuci, dan lain-lain. Anak bisa dilibatkan atau anak dibuatkan agenda kegiatan tersendiri yang bisa dilakukan untuk menstimulus kecerdasannya. Siapkan anak ketika berhadapan dengan teman yang membawa ppengaruh buruk dengan membekali anak kebiasaan baik di rumah, perkataan yang baik, suka beribadah, dan gemar melakukakan kebaikan. Melibakan anak dalam aktifitas dakwah ibu sehingga anak meneladani ibunya menjadi da'i cilik yang selalu mengkritisi dan menasehati orang lain bila keluar dari koridor kebiasaanya (Ikhwan et al. 2019). Mencurahkan seluruh perhatian dan kasih sayang yang ibu miliki untuk anak, apakah saat anak menjalankan ketaatan dengan baik atau dalam kesusahan mengajak anak untuk menjalankan pembelajaran. Membangun komunikasi yang intens, penuh kebahagiaan, kesenangan dan ketentraman batin anak, saat meraih prestasi atau saat menghadapi masalah dengan teman. Selanjutnya yang tidak boleh dilupakan adalah berdo'a untuk kemudahan mendidik anak, ketajaman lisan ibu dalam memberikan pelajaran dan menasehati anak (Tanjung 2017:160-161).

Selanjutnya, Pendidikan RT lebih rendah dari suaminya, dimana RT lulusan S1 dan suaminya S2. Menurut Faucault dilihat dari segi pendidikan suami RT yang lebih berkuasa dalam menetukan pendidikan anak. Dalam keluarga RT bukan pendidikan yang menentukan suami atau istri yang berkuasa, tetapi karena suami adalah qowwam (pemimpin) sehingga keputusan berada pada suami. Suami RT yang fokus pada bidang pendidikan juga sangat mempengaruhi dalam pengambilan keputusan pendidikan anak. Selain itu, semua biaya pendidikan anak ditanggung suami RT karena itu adalah tanggungjawabnya. RT dan suami menentukan pendidikan anak berdasarkan visi misi keluarga yang telah disepakati bersama, tetapi jika ada pilihan pendidikan yang berbeda RT mendahulukan pilihan suaminya, karena bagi RT suami adalah pemimpin baginya dan lebih berpikir ke depan untuk kebaikan anaknya.

Pendidikan HN lebih rendah dari suaminya, dimana HN lulusan S1 dan suaminya S2. Berdasar teori Faucault suami HN lebih berkuasa dalam pengambilan keputusan jika diliha dari tingginya pendidikan. Dalam keluarga HN bukan karena tingginya pendidikan yang memepengaruhi pengambilan keputusan, tetapi karena ketaatan HN pada suami yang menjadi pemimpinnya dalam keluarga, sehingga apa yang dikatakan atau apa yang diputuskan oleh suami itulah yang dijalankan oleh HN, dalam setiap hal HN meminta izin pada suaminya. HN mendidik anak dan mengarahkan anaknya untuk bersedia menerima pendidikan yang telah dipilihkan. suami HN yang mengambil keputusan dan HN mengikuti semua keputusan suami.

Bentuk sinergi ayah dan ibu dalam mewujudkan kepribadian anak. dalam hal ini dibutuhkan diskusi untuk membahas tentang tujuan, konsep, metode dan cara pendidikan juga sarana prasarana yang dibutuhkan. Sebab pendidikan anak adalah kewajiban berdua bukun kewajiban sepihak ibu maupun ayah sendiri, ayah dan ibu juga akan dimintai pertanggung jawaban oleh Allah tentang anak mereka, bahkan ayah dimintai pertanggung jawaban terhadap ibu dari anak-anaknya. Jika ayah cenderung ke luar kota karena kewajiban nafkah dan dakwah, tidak mengabaikan perhatiannya terhadap pendidikan anak, meskipun pada mengevaluasi setiap harinya, misalkan menanyakan hafalannya, perkembangan pemahaman, ketaatan pada Allah. Ayah bisa memberikan saran ketika ibu menghadapi kesulitan dalam mendidik anak (Tanjung 2017).

\section{Simpulan}

Keluarga adalah institusi ketahanan yang terkuat dan setiap manusia begitu terikat pada keluarga, karena setiap orang dilahirkan dalam keluarga. Setiap keluarga berfungsi sebagai pengantar untuk masyarakat yang lebih besar, sebagai hubungan pribadi dengan struktur sosial yang lebih besar. Kekuatan sosial keluarga adalah aspek yang tidak dapat ditemukan di institusi lain. Ada beberapa hasil yang diperoleh dari penelitian ini. Pertama, suami lebih dominan ketika dia memiliki akses ke pengetahuan dalam pendidikan, kemampuan ekonomi untuk memenuhi semua kebutuhan suami, dan pemahaman agama Ar-rijalu Qowwamuna Alan-Nisa. Kedua, istri lebih dominan ketika dia memiliki 
akses ke pengetahuan tinggi dan keterampilan ekonomi yang sama dengan suaminya. Ketiga, diskusi dan musyawarah adalah jalan yang dipilih oleh suami dan istri untuk mempertimbangkan sekolah. Terakhir, sekolah Hidayatullah dipilih untuk pendidikan anak-anak mereka karena mereka menganggapnya sebagai tempat terbaik untuk menjaga agama.

Relasi kuasa menurut Faucault adalah berdasarkan pengetahuan atau pendidikan, tetapi terdapat pengaruh lain seperti akses pengetahuan suami dan istri pada pendidikan, pemahaman agama Ar-rijalu qowwamuna alan-nisa' (laki-laki adalah pemimpin bagi wanita), dan biaya hidup keluarga termasuk untuk pendidikan anak. Tingginya pengetahuan atau pendidikan suami tidak selalu mempengaruhi kekuasannya dalam pengambilan keputusan pendidikan anak. Diskusi maupun musyawarah adalah jalan yang dipilih suami dan istri untuk mempertimbangkan sekolah. Ibu Mushida lebih memilih Hidayatullah dalam menyekolahkan anak untuk mejaga agama (aqidah, ibadah, dan akhlak anak).

\section{Daftar Pustaka}

Abbott P \& Wallace C (Eds.) (2016) Gender, Power and Sexuality. Springer.

Ahmad K (1974) Family life in Islam. Islamic Foundation.

Anderson KJ \& Minke KM (2007) Parent involvement in education: Toward an understanding of parents' decision making. The Journal of Educational Research 100 (5):311-323.

Badawi H (2005) Parental reasons for school choice: A case study of an Islamic school in the United States of America (Doctoral dissertation, University of Minnesota).

Ball S J (2012) Foucault, Power, and Education. Routledge.

Bosetti L (2004) Determinants of school choice: Understanding how parents choose elementary schools in Alberta. Journal of Education Policy 19 (4):387-405.

Carolan MT, Bagherinia G, Juhari R, Himelright J, Mouton-Sanders M (2000) Contemporary Muslim families: Research and practice. Contemporary Family Therapy 22 (1):67-79.

Daniel KL, Prue C, Taylor MK, Thomas J, Scales M (2009) 'Learn the signs. Act early': A campaign to help every child reach his or her full potential. Public Health 123:e11-e16.

Denessen E, Driessena G, Sleegers P (2005) Segregation by choice? A study of group-specific reasons for school choice. Journal of Education Policy 20 (3):347-368.

Dornbusch SM, Ritter PL, Mont-Reynaud R, Chen ZY (1990) Family decision making and academic performance in a diverse high school population. Journal of Adolescent Research 5 (2):143-160.

Freire P (1985) The Politics of Education: Culture, Power, and Liberation. Greenwood Publishing Group.

Gurko TA (2017) New family forms: tendencies of spreading and concepts. Sociological Studies 11 (11):99-110.

Ikhwan A, Biantoro OF, Rohmad A (2019) The Role of the Family in Internalizing Islamic Values. Dinamika Ilmu 19 (2):323-335.

Mitchell BA (2017) Family Matters: An Introduction to Family Sociology in Canada. Canadian Scholars' Press.

Newman, DM \& Grauerholz E (2002) Sociology of Families. Pine Forge Press.

Predelli LN (2004) Interpreting gender in Islam: A case study of immigrant Muslim women in Oslo, Norway. Gender \& Society 18 (4):473-493.

Putri DPK, Lestari S (2016) Pembagian peran dalam rumah tangga pada pasangan suami istri Jawa. Jurnal Penelitian Humaniora 16 (1):72-85.

Wilson P \& Pahl R (1988) The changing sociological construct of the family. The sociological Review 36 (2):233-266. 